\title{
The Good Governance Levels of Leaders of Local Administrative Organizations in the Phetchabun Province
}

\author{
Sombut Boonleaing ${ }^{1}$ \\ ${ }^{1}$ Faculty of Humanities and Social Sciences, Phetchabun Rajabhat University, Thailand \\ Correspondence: Sombut Boonleaing, Faculty of Humanities and Social Science, Phetchabun Rajabhat \\ University, Phechabun Province 67000, Thailand. E-mail: sombutdpa@gmail.com
}

Received: July 15, 2014 Accepted: August 3, 2014 Online Published: August 22, 2014

doi:10.5539/ass.v10n18p219 URL: http://dx.doi.org/10.5539/ass.v10n18p219

\begin{abstract}
The objectives of this study were to study the good governance levels of local administrative organizations in the Phetchabun province. This study employed quantitative methods in which the researcher administered 400 questionnaires and analyzed data using descriptive methods such as percentage, mean, and standard derivation. The results indicated the overall good governance levels in the Phetchabun Province were high: the most important is responsibility (mean $=3.85$, S.D. $=0.91)$, followed by the rule of law $($ mean $=3.92$, S.D. $=0.93)$, morality $($ mean $=3.85$, S.D. $=0.91)$, accountability $($ mean $=3.57$, S.D. $=0.98)$, cost-effectiveness $($ mean $=3.48$, S.D. $=1.00)$, and participation $($ mean $=3.18$, S.D. $=0.98)$. The problem for leaders of local administrative organizations in Phetchabun province are that many development policies and activities are led by the central government and cannot develop and respond to the requirements of the local area.
\end{abstract}

Keywords: good governance, leaders, local administrative organization

\section{Introduction}

Local government in Thailand has two main types. The first is the general form, including provincial administrative organizations, municipalities, and subdistrict (tambon) administrative organizations. The second type is a specific form. There are two local governments in a specific area: the Bangkok Metropolitan Organization and Pattaya City (Krueathep, 2004). Local administration organizations (LAOs) in Thailand come in several types. Provincial administrative organizations (PAOs) and subdistrict administrative organizations (SAOs) are led by chief executives. City, town, and subdistrict municipalities are led by mayors. LAOs are the form of local government most affected by regional development. They are closer to the people. Their policies are designed for local development.

However, the practice of good governance concepts in LAOs still faces many problems, some stemming from lack of good governance in the LAO leadership. For example, Sopchokchai (2001) suggested that SAOs can easily be corrupted, lack transparency and the participation of the people, and have conflicts of interest and corruption in many areas. Damrongchai (2013) stated that the good governance concept is the one lesson that helps and reduces corruption.

Leaders of LAOs in Thailand are top management who can lead their organizations into good practices and work under a good governance concept; alternatively, they can lead, influence, and command their organizations with a lack of transparency. The study of Sonsurina (2013) found problems of some LAOs' leaders and staff in the Wichianburi District, Phetchabun Province, such as the problem of knowledge. LAOs' leaders and staff should have more training in the system and the procurement of modern tools and equipment, and to give them ethical knowledge in working is also important. In addition, Pornleesangsuwon's (2009) study of leadership of the chief executives of the Subdistrict Administration Organization in the Khao Kho District of Phetchabun Province found that the major problem was the chief executives not applying the merit system and morality principles for management in their organizations. This paper's research question is to determine the good governance level of leaders of LOAs in the Phetchabun Province, and it will discuss the good governance level and the lack of good governance of leaders of LAOs in the Phetchabun Province. The researcher hopes this paper will provide information to other researchers and help leaders of local governments to practice good governance leadership. 


\section{Objective}

The purpose of this study is to examine the good governance levels of leaders of local administrative organizations in the Phetchabun Province.

\section{Methodology}

The location of this study is the Phetchabun Province of Thailand. Phetchabun has 128 LAOs: 1 PAO, 3 city municipalities, 20 subdistrict municipalities, and 104 SAOs. The population of this study is the residents of the Phetchabun Province.

The researchers provided 400 questionnaires to the population and calculated a sample size using Yamane's formula (1973, p. 725) at $95 \%$ of the significant level. The closed-ended questionnaire offered five options for each response: strongly agree, agree, moderately agree, disagree, and strongly disagree. The interpretation divided the question scales into a 5-point scale: higher, high, moderate, low, and lowest (5.00-4.5, 4.49-3.50, $3.49-2.50,2.49-1.50$, and 1.49-1.00); the researchers analyzed this data using mean and standard deviation. The location of this study is shown in Figure 1.

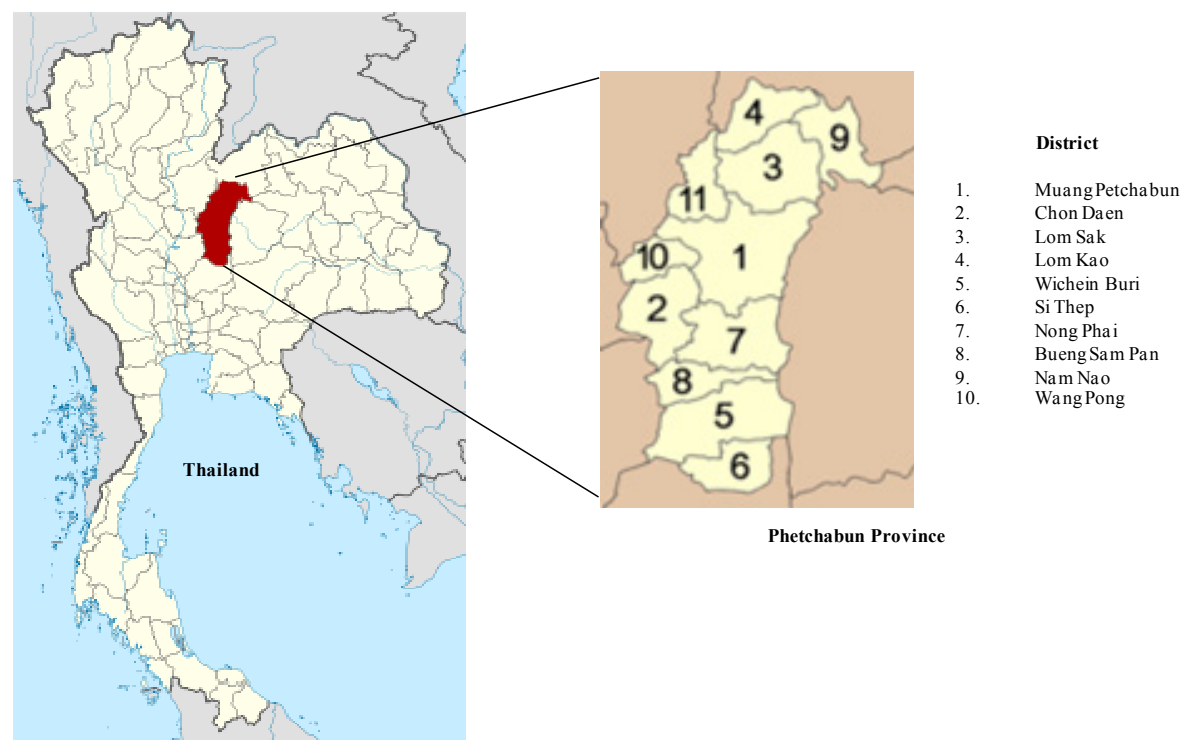

Figure 1. Phetchabun province

From: http://simple.wikipedia.org/wiki/Phetchabun_Province

\section{Literature Reviews and Conceptual Framework}

In this paper, we used two concepts to develop the conceptual framework. The first concept is leadership. The second concept is good governance.

Leaders of LAOs are important to the organizations' success or failure because LAO leaders influence or command all of an organization's employees (Boonleaing, 2014). Leadership is influence to change other people on an individual or group level to achieve their target goals (Northouse, 2013, p. 5). Leadership can motivate other people to perform their jobs as the leaders want (Tannenbaum \& Schmidt, 1973). The characteristics of leadership are different from the position level in organizations; the important characteristics of leaders are potential, trustworthiness, participation, and self-confidence (Nichols \& Cottrell, 2014). In addition, Boonleaing et al. (2010) explained the characteristics of good leadership as vision, education, knowledge, and desire to develop oneself, high morals, concern for one's work and job tasks, responsibility to duty, accountability, and participation with all stakeholders.

After the year 1970, "good governance" has been the method used by modern bureaucratic states to solve problems. Good governance has more focus on performance accountability, responsible government, and procedure accountability to change the work process to achieve the target goal (Jansiri, 2014). The good governance concept was concentrated on the intellectual debates of the 1980s and 1990s, and good governance is related to the ideas such as decolonization, localization, and human rights (Weiss, 2010). Increasing the quality of governance will lead to residents and citizens being more satisfied and more trusting (Bouckaert, 2003). The 
study of Lockwood (2010) presented 7 principles of good governance: legitimacy, transparency, accountability, inclusiveness, fairness, connectivity, and resilience. In addition, in this paper, researchers used the concept of the Office of the Prime Minister of Thailand (1999), which has divided the aspects of good governance into 6 dimensions:

1) The rule of law-to works and manages fairly under the rule of law;

2) Morality-to work and decide morally, for public service, and honestly;

3) Accountability-to work under transparency and without corruption;

4) Participation-to give opportunities to all stakeholders to share their ideas for development programs and use participation in any process of work tasks and then use the ideas of others in making final decisions;

5) Responsibility-to emphasize duty, work with social responsibility, concern for and quick response to problems, respect for others with different ideas, and admitting one's mistakes;

6) Cost effectiveness-to use the limited resources for maximum benefits for public service and protect natural resources sustainability.

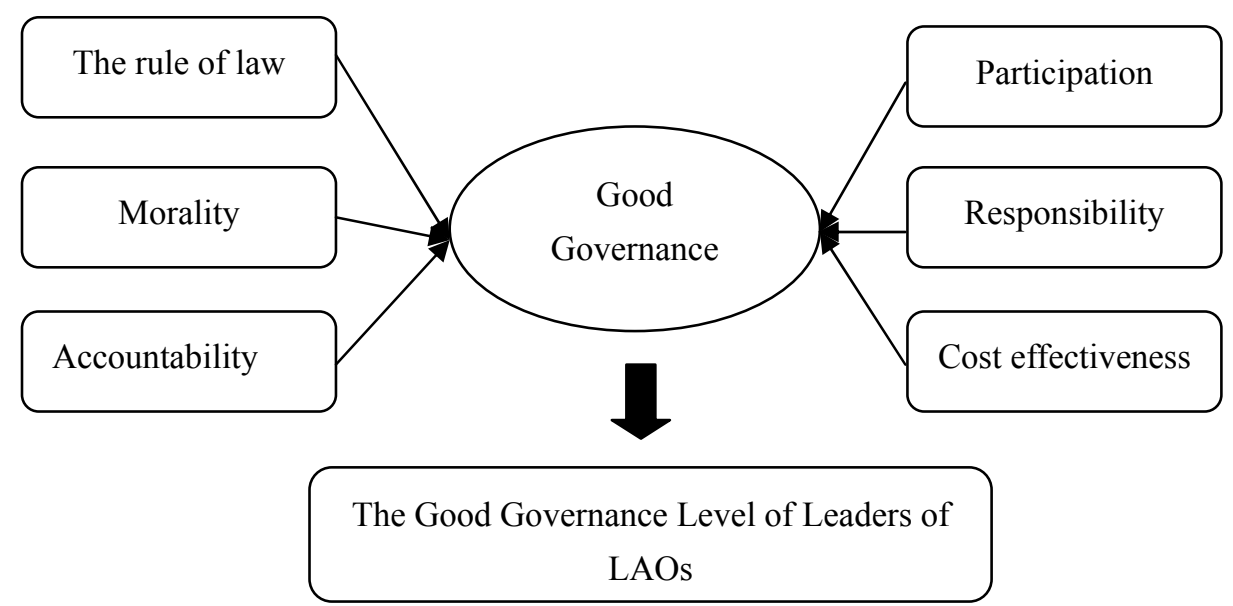

Figure 2. Conceptual framework

\section{Results}

We found the population agreed the LAOs in the Phetchabun Province had high levels of good governance $($ Mean $=3.66$, S.D. $=0.94)$. The highest mean score was accountability $($ Mean $=3.98$, S.D. $=0.88)$, and the lowest score was cost effectiveness (Mean $=3.18$, S.D. $=0.98$ ), as shown in Table 1 .

Table 1. Mean and standard deviation of good governance levels of LAOs in the Phetchabun Province

\begin{tabular}{llll}
\hline Good governance & $\bar{X}$ & S.D. & Level \\
\hline 1. The rule of law & 3.92 & 0.93 & High \\
2. Morality & 3.85 & 0.91 & High \\
3. Accountability & 3.98 & 0.88 & High \\
4. Participation & 3.48 & 1.00 & Moderate \\
5. Responsibility & 3.57 & 0.98 & High \\
6. Cost effectiveness & 3.18 & 0.98 & Moderate \\
Total & 3.66 & 0.94 & High \\
\hline
\end{tabular}

As shown in Table 1, the highest level of agreement from the population was accountability (Mean $=3.98$, S.D. $=0.88)$. The second was the rule of law $($ Mean $=3.92$, S.D. $=0.93)$. The third was morality $($ Mean $=3.85$, S.D. $=$ $0.91)$. The fourth was responsibility (Mean $=3.57$, S.D. $=0.98$ ). The fifth was participation $(\mathrm{Mean}=3.48$, S.D. $=$ 1.00). The lowest score was cost effectiveness $($ Mean $=3.18$, S.D. $=0.98)$. The levels of good governance concepts used by the management of LAOs in the Phetchabun Province are explained in the following section. 
1) Accountability: The high level of accountability of leaders of LAOs in Phetchabun meant the residents of the province were satisfied with the reduction in corruption issues from 2012 to 2014. Residents complained about more than 10 corruption issues in 2012 and 2013; however, in 2014 (January-June), the researcher found 3 issues. In addition, many LAOs in Phetchabun have multiple channels for residents who would like to complain and give ideas for development, and the leaders and officers of LAOs were quick to respond. In addition, leaders of LAOs in Phetchabun were ready to reverse management decisions for which they received complaints.

2) The rule of law: The leaders of LAOs in Phetchabun managed under the law and always checked complaints from residents to improve the work and management of LAOs. In addition, LAOs have revised the conditions of the law to respond to present situations.

3) Morality: The leaders of LAOs worked in public service with honesty and gave equal opportunity to all officers under their command and to all communities and residents in development issues. Morality is important to leadership: Ebbesson (2010) stated that leaders should be more concerned with and use morality for decision making, especially in issues such as health policy, economics, and the environment.

4) Responsibility: Leaders of LAOs in Phetchabun have applied their skills and abilities to their duties and work tasks. They have also been responsive in their decisions. They have also shown a willingness to solve problems they create and develop new methods for management. In addition, the leaders in LAOs have shown respect for the people around them and have been supportive and helpful.

5) Participation: Participation is the core management skill for LAOs because public policies and all activities of public service should come from the residents' requirements. However, many leaders of LAOs failed to use participation from all stakeholders (residents, businesses, and other government agencies in the area) to discuss and set up policy and development activities. Many leaders in Phetchabun followed the policies of their political parties and did not perform surveys or research before instituting policies.

6) Cost effectiveness: This lowest score of good governance levels for leaders of LAOs in the Phetchabun Province (moderate level) meant budgets for development were not appropriate to the requirements of residents and the community. For example, most of the leaders of LAOs focused on infrastructures such as roads; however, many residents requested more social welfare, such as health care provisions. In addition, the monthly pension for older people is $500 \mathrm{baht} / \mathrm{month}$ (approximately $16 \mathrm{US}$ dollars/month) and limits the number of participants. Therefore, LAOs in Phetchabun should designate sufficient funds to distribute to all older people in the community. Khamngae et al. (2014) suggested that LAOs should set up a new department to serve and support the elderly.

The research also revealed that LAOs' leaders in the Phetchabun Province were somewhat controlled or dominated by the central government because the budget and fiscal year of LAOs depend on the central government's approval. In addition, many years ago, the central government transferred many jobs and duties to LAOs; however, the central government still controls the budget and has not increased LAO budgets, and LAOs have only limited authority to gather local tax revenue. Because LAOs' incomes still depend on the central government and politicians (such as national representatives), if LAOs' leaders wish to receive increased funds, they must follow the policies and development activities of the central government, which might not meet the requirements of the local area.

\section{Conclusions}

The good governance agenda is a goal of reducing poverty for many countries (Grindle, 2004). The importance of leadership can make an organization successful, and without leadership, a group of people can quickly degenerate into argument and conflict between people in the group (Mills, 2005). In this paper, we presented the levels of good governance of leaders of LAOs in the Phetchabun Province, Thailand. The study found that the level of good governance was high because many LAO leaders attempted to provide public services to satisfy local residents and all stakeholders in their electorate areas (leaders of LAOs are elected). However, the control of the budget and fiscal year by the central government is an obstacle that leaders of LAOs have not overcome. The leaders may subordinate policy ideas to develop local regions to the plans of the central government to attract or maintain access to the central government's funds for development. This issue is related to the lowest score in the study's survey: cost effectiveness. In addition, in managing costs, Kardos (2012) suggested that leaders should consider sustainable development in all aspects-economic, social, and environmental-before making a decision.

Finally, to develop the good governance level of LAOs, LAO leaders should participate with all stakeholders in setting up policies for development and activities for public service because participation from residents, 
business owners, and all stakeholders can make a LAO's policies and activities meet the requirements of the local community. In addition, the Department of Local Administration, Ministry of Interior, and Thai Government compose the responsiveness unit to set up the training program to encourage the good governance concept knowledge to leaders of LAOS, so they should set up more training programs and emphasize good governance, morals, and ethics. In addition, the Department of Local Administration should set up more departments for external audits and financial checks on LAOs because the number of staff from the Office of the Auditor General of Thailand is not enough to investigate and audit LAOs (the Office of the Auditor General of Thailand is auditor and investigator of all government offices of the Thai government).

\section{Policy Suggestions for the Central Government}

1) The central government should give more opportunities for tax revenue to LAOs. The current legal limitations necessitate that most tax revenue is operated by the central government.

2) The Department of Local Administration, Ministry of the Interior should set up more training programs about good governance for leaders of LAOs.

3) The central government should decentralize, releasing more of its command and control to LAOs to allow more responsiveness to local issues and problems.

\section{References}

Boonleaing, S. (2014). The characteristics of leadership suitable to management when using the good governance concept in Local Administrative Organizations in Petchabun Province. Proceedings of the Second National Conference on Public Affairs Management, August 7, 2014; KhonKaen, Thailand.

Boonleaing, S., Ngamsanit, S., Bunjetrit, S., Muldet, K., Kroeksakul, P., \& Sakolnakorn, T. P. N. (2010). The leadership characteristics and efficiency of local administrative organizations: A case study of local administrative organizations in the lower north region of Thailand. International Business \& Economics Research Journal, 9(12), 119-122.

Bouckaert, G. (2003). Comparing measures of citizen trust and user satisfaction as indicators of 'Good Governance': Difficulties in linking trust and satisfaction indicators. International Review of Administrative Sciences, 69(3), 329-343.

Damrongchai, P. (2013). Good governance \& Counter corruption in Thailand. Retrieved July 3, 2014, from http://tri.or.th/wp-content/uploads/2013/04/prasit_e.pdf

Ebbesson, J. (2010). The rule of law in governance of complex socio-ecological changes. Global Environmental Change, 20(3), 414-422. http://dx.doi.org/10.1016/j.gloenvcha.2009.10.009

Grindle, M. S. (2004). Good enough governance: Poverty reduction and reform in developing countries. Governance, 17(4), 525-548. http://dx.doi.org/10.1111/j.0952-1895.2004.00256.x

Jansiri, N. (2014). Book review: Democratic governance. Journal of Humanities and Social Sciences Suratthani Rajabhat University, 6(1), 221-228.

Kardos, M. (2012). The reflection of good governance in sustainable development strategies. Procedia-Social and Behavioral Sciences, 58, 1166-1173. http://dx.doi.org/10.1016/j.sbspro.2012.09.1098

Khamngae, S., Boonleaing, S., Bungchan, N., \& Sakolnakorn, T. P. N. (2014). Social welfare needs and policies for elderly people in Thailand: A case study in Pitsanulok community. Asian Social Science, 10(12), 142-148. http://dx.doi.org/10.5539/ass.v10n12p142

Krueathep, W. (2004). Local government initiatives in Thailand: Cases and Lessons Learned. Asia Pacific Journal of Public Administration, 26(6), 217-239. http://dx.doi.org/10.1080/23276665.2004.10779294

Lockwood, M. (2010). Good governance for terrestrial protected areas: A framework, principles and performance outcomes. Journal of Environmental Management, 91(3), 754-766. http://dx.doi.org/10.1016/j. jenvman.2009.10.005

Mills, D. Q. (2005). Chapter 1: The important of leadership. Retrieved July 30, 2014, from http://www.cafanet. com/LinkClick.aspx?fileticket $=$ qwswE8roe74\%3D\&tabid $=96$

Nichols, A. L., \& Cottrell, C. A. (2014). What do people desire in their leaders? The role of leadership level on trait desirability. The Leadership Quarterly, 25(4), 711-729. http://dx.doi.org/10.1016/j.leaqua.2014.04.001

Northouse, P. G. (2013). Leadership: Theory and practice (6th ed.). California: SAGE.

Office of the Prime Minister. (1999). The Regulation of Good Governance. Bangkok: Office of the Prime 
Minister.

Pornleesangsuwon, W. (2009). The comparison of management administration regarding leadership of the chief executives between the Khao Kho and the Thung Samo Subdistrict Administrative Organizations in Khao Kho District of Phetchabun province. Retrieved July 23, 2014, from http:/www.wiruch.com/articles\% 20for\%20article/thesis\%20title\%20and\%20abstract\%20mpa5\%202552.pdf

Raz, J. (1977). The rule of law and its virtue. In N. Sadeleer (Ed.), The Law Quarterly Review 93 (pp. 195-211). Implementing the Precautionary Principle: Approaches from the Nordic Countries, EU and USA. Earthscan, London.

Sonsurina, P. (2013). The Management of Local Wisdom of Sub-District Administration Organization in Wichianburi District, Phetchabun Province. Retrieved July 23, 2014, from http://www.mcu.ac.th/En/thesis content_desc.php?ct=1\&t_id=1364

Sopchokchai, O. (2001). Good local governance and anti-corruption through people's participation: A case of Thailand. Retrieved July 2, 2014, from http://www.worldbank.org/publicsector/.../tao-e1.doc

Tannenbaum, R., \& Schmidt, W. H. (1973). How to choose a leadership pattern. Retrieved May 10, 2014, from http://www.expert2business.com/itson/Tannenbaum.pdf

Weiss, T. G. (2010). Governance, good governance and global governance: Conceptual and actual challenges. Third World Quarterly, 21(5), 795-814. http://dx.doi.org/10.1080/713701075

Yamane, T. (1973). Statistics an introductory analysis. New York: Harper \& Row.

\section{Copyrights}

Copyright for this article is retained by the author(s), with first publication rights granted to the journal.

This is an open-access article distributed under the terms and conditions of the Creative Commons Attribution license (http://creativecommons.org/licenses/by/3.0/). 